\title{
Evaluation of Serum Testosterone Level in Patients with Psoriasis and Its Correlation to Severity of the Disease
}

Amira Mohamed Abdelmonem*, Enayat Mohamed Atwa, Ayman El Sayed Ahmed Yosef.

Department of Dermatology, Venereology and Andrology, Faculty of Medicine, Zagazig University, Egypt *Corresponding Author: Amira Mohamed Abdelmonem, Mobile: (+20)1012306261, Email:dramiramohamed360@gmail.com

\begin{abstract}
Background: Psoriasis is a chronic inflammatory, immune-mediated systemic disease with skin manifestations that typically follow a relapsing and remitting course. The most common form, plaque psoriasis, occurs in $\sim 80-90 \%$ of psoriatic patients. Objective: The aim of the current work was to evaluate level of serum testosterone in psoriasis male patients and its relation to severity of the disease.

Patients and methods: This cohort study included a total of 35 psoriatic patients, attending At Outpatient Clinic, Dermatology and Venereology Department, Zagazig University Hospital, Egypt. This study was conducted between January 2020 to October 2020. Serum free and total testosterone and total cholesterol were measured.

Result: About two thirds of the studied group $(71.4 \%)$ had normal testosterone level and $(28.6 \%)$ had low testosterone level.

Conclusion: Low serum total and free testosterone levels in male psoriasis patients are present and they correlate with disease severity.
\end{abstract}

Keywords: psoriasis, testosterone, PASI score.

\section{INTRODUCTION}

Psoriasis is a chronic inflammatory disease of the skin that affects about $2-3 \%$ of the population and greatly impairs the quality of life of affected individuals (1). Psoriasis affects mainly skin, nails and joint and is characterized by the presence of sharply demarcated, red plaques with adherent silvery white scales and a tendency for symmetrical distribution over the body ${ }^{(2)}$. The etiology of psoriasis is not fully understood, but it may be the net result of the interaction among genetic, environmental and immunological factors ${ }^{(3)}$.

The pathogenesis of psoriasis seems to be driven by the interaction between innate immune cells, adaptive immune cells and keratinocytes, in a process mediated by cytokines (including interleukins (IL)-6, IL-17 and IL-22, interferon- $\gamma$ and tumor necrosis factor$\alpha$ ) and other signaling molecules ${ }^{(4)}$. This leads to an inflammatory process with increased proliferation of epidermal cells, neo-angiogenesis and infiltration of dendritic cells in the skin ${ }^{(4)}$. Chiricozzi et al. ${ }^{(5)}$ pointed at the cytokines of the IL-23/IL-17 axis as the important players in the pathogenesis of psoriasis. Psoriasis lesions reveal significant expression of IL-23 and its receptor in psoriatic lesional skin and in blood circulation ${ }^{(6)}$. As IL-23 stimulates TNF- $\alpha$ and IL-22, its high expression has been proposed as a causative factor in the onset of psoriasis ${ }^{(7)}$.

Interleukin-22, cytokine of the IL-10 family, it stimulates proliferation of keratinocytes. The interaction between IL-22 and IL-17 results in activation of proinflmmatory cytokines and chemokines and increases vascular endothelial growth factor (VEGF) production from keratinocytes ${ }^{(\mathbf{8})}$.

Hormones, especially sex steroid hormones, have a major role in psoriasis pathogenesis due to their effect on keratinocyte proliferation along with their variable biological and immunological impact on skin. The lower levels of total testosterone, free testosterone, and sex hormone-binding globulin were found to be associated with the metabolic syndrome. The latter is considered a sensitive biomarker for insulin resistance and systemic inflammation in psoriatic patients ${ }^{(\mathbf{9})}$.

This study was aimed to evaluate level of serum testosterone in psoriasis male patients and its relation to severity of the disease.

\section{PATIENTS AND METHODS}

This cohort study included a total of 35 psoriatic patients and 15 apparently healthy males, attending At Outpatient Clinic, Dermatology and Venereology Department, Zagazig University Hospital, Egypt. This study was conducted between January 2020 to October 2020.

\section{Ethical Consideration:}

This study was ethically approved by the Research Ethics Committee of Zagazig University Hospital. All included participants gave a written informed consent before being in the study.

This work has been carried out in accordance with The Code of Ethics of the World Medical Association (Declaration of Helsinki) for studies involving humans.

Inclusion criteria: Male patients, age 18 years or older, and suffering from psoriasis for longer than one year.

Exclusion criteria: Age less than 18 years, and disease duration less than one year.

\section{Clinical assessment of the patients:}


All the patients were subjected to full medical history and complete general and local examination. The Psoriasis Area and Severity Index (PASI) was used to evaluate the patients with psoriasis Vulgaris. The disease severity was considered as; mild if PASI $<15$, moderate if PASI 15-25, and severe if PASI $>25$ (10).

\section{Assessment of serum level of testosterone:}

1. Estimation of serum free and total testosterone level. Blood samples were taken between 8 and 10 am from all patients included in the study. Total testosterone $(\mathrm{ng} / \mathrm{ml})$ was analyzed using cobas $\mathrm{E}$ 411 analyzer. Free testosterone $(\mathrm{ng} / \mathrm{ml})$ was analyzed using the enzyme-linked immunosorbent assay (ELISA).

2. Total cholesterol was measured by a colorimetric $\operatorname{method}^{(11)}$.

\section{Statistical analysis}

Data were checked, entered and analyzed using SPSS version 23 for data processing. Data were summarized using (The arithmetic mean $(\overline{\mathrm{X}})$ and The standard deviation (SD)). The comparison was done using (The student " $t$ " test, Mann Whitney test, Chisquare test (X2), ANOVA (F-test) test, Correlation coefficient test and The Paired " $t$ " test).P value less than 0.05 was regarded as statistically significant.

\section{RESULTS}

The present study included 35 male patients suffering from psoriasis and 15 apparently healthy males, their average ages was $(47.9 \pm 12.4)$ ranged from 21-75 years and average disease duration was $(9.8 \pm$
7.1) ranged from 1.5 to 28 years. The clinical data of psoriatic group showed that most of the patients presented with psoriasis, PASI scores varied from (4.2 to 41$)$ with a mean of $(17.2 \pm 7.2)$.

Five patients presented with mild PASI (14.3\%), 19 patients with moderate PASI $(54.3 \%)$ while 11 patients presented with severe PASI score (31.4\%). Associated chronic diseases were found in $57.1 \%$ of the psoriasis group (10 cases with hypertension, 12 cases with DM, 2 cases with gout, 1 case with coronary artery disease, 1 case with renal insufficiency and 1 case with bronchial asthma) and regarding obesity about 15 patients were obese their percentage were $(42.9 \%)$. Relation between PASI Score and patients' characteristics (Table 1).

The average total testosterone level was $(5.1 \pm 1.5$ $\mathrm{ng} / \mathrm{ml}$ ) ranged from (2.91 to 7.93) and free testosterone level was (12.5 $\pm 3.5 \mathrm{ng} / \mathrm{ml})$ ranged from (6.9 to 18.9). About two thirds of the studied group $(71.4 \%)$ had normal testosterone level and $(28.6 \%)$ had low testosterone level and sexual complaints so need a treatment (Finger 1). There was statistically significant increase in total and free testosterone level among patients with mild than moderate than severe PASI score $(\mathrm{P}$ value $=0.001)$ while cholesterol level was statistically significantly higher among patient with severe than moderate than mild PASI score (P value $=0.005$ ).

There was statistically significant higher cholesterol level among patients with low testosterone than patients with normal testosterone level, while regarding age disease duration, obesity, presence of family history or chronic disease, there was no statistically significance relation with testosterone level (Table 2).

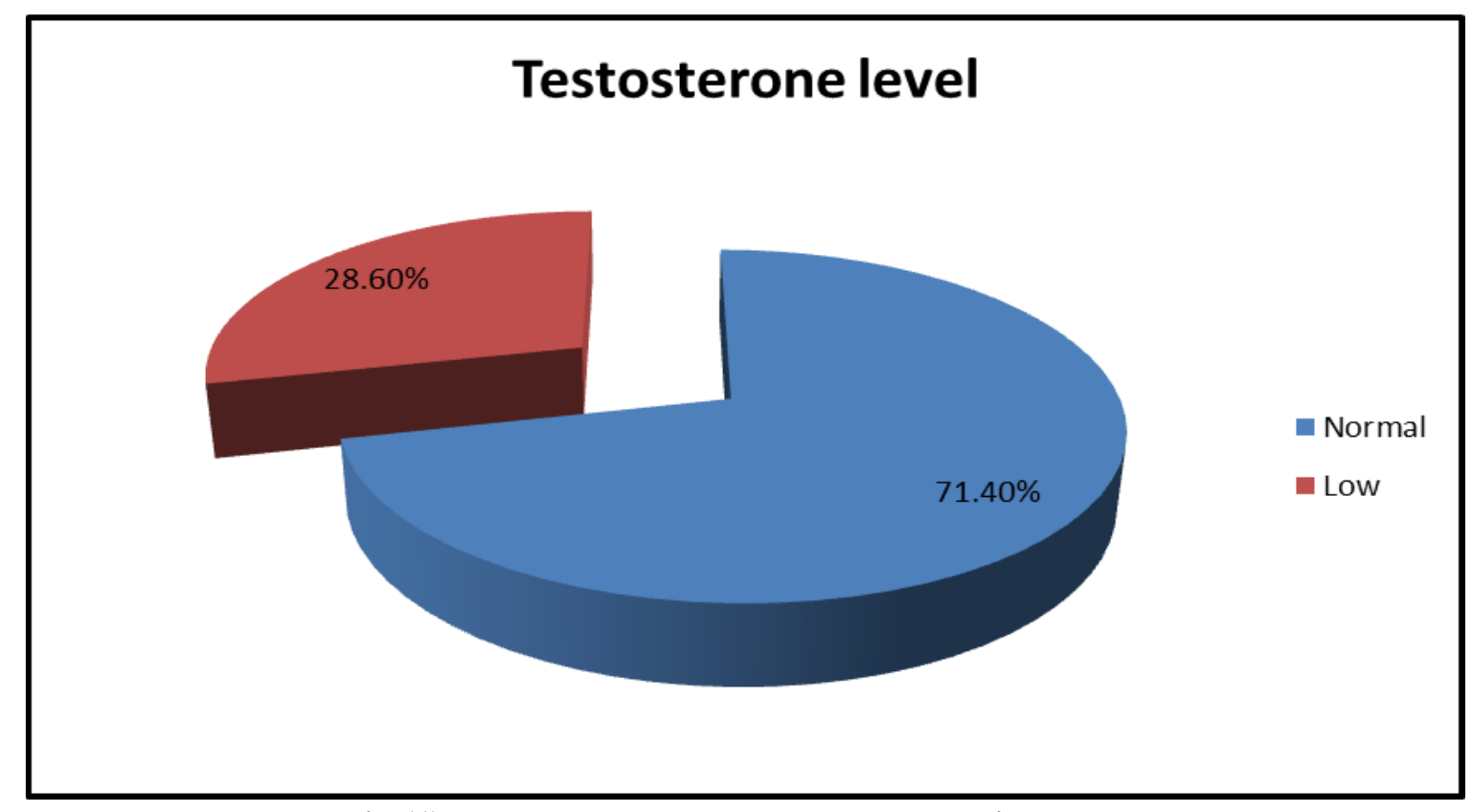

Fig (1): Testosterone level among the studied group.

Table (1): Relation between PASI Score and patients' characteristics 


\begin{tabular}{|c|c|c|c|c|c|}
\hline Variables & $\begin{array}{l}\text { Mild PASI } \\
\text { No: } 5\end{array}$ & $\begin{array}{l}\text { Moderate PASI } \\
\text { No: } 19\end{array}$ & $\begin{array}{c}\text { Severe PASI } \\
\text { No: } 4\end{array}$ & Test & P-value \\
\hline $\begin{array}{l}\text { Age (years) } \\
\text { Mean } \pm \text { SD } \\
\text { Range } \\
\end{array}$ & $\begin{array}{l}39.6 \pm 12.7 \\
(22-52)\end{array}$ & $\begin{array}{c}50.9 \pm 12.7 \\
(21-75) \\
\end{array}$ & $\begin{array}{c}46.4 \pm 10.5 \\
(33-63)\end{array}$ & $\mathrm{K} . \mathrm{W}=1.8$ & 0.2 \\
\hline $\begin{array}{l}\text { Disease duration } \\
\text { Mean } \pm \text { SD }\end{array}$ & $3.9 \pm 3.1$ & $10.5 \pm 7.8$ & $(11.2 \pm 63)$ & $\mathrm{K} . \mathrm{W}=2.1$ & 0.1 \\
\hline $\begin{array}{l}\text { Cholesterol level }(\mathrm{mg} / \mathrm{dl}) \\
\text { Mean } \pm \text { SD }\end{array}$ & $174.8 \pm 4.4$ & $181.4 \pm 9.8$ & $229.1 \pm 47.9$ & $F=64$ & $0.005^{*}$ \\
\hline $\begin{array}{l}\text { Total testesterone level } \\
(\mathrm{ng} / \mathrm{ml}) \text { Mean } \pm \text { SD }\end{array}$ & $7.1 \pm 1.04$ & $5.04 \pm 1$ & $4.2 \pm 1.0$ & $\mathrm{~F}=9.1$ & $0.001^{* * *}$ \\
\hline $\begin{array}{l}\text { Free testesterone } \\
(\mathrm{ng} / \mathrm{ml}) \text { Mean } \pm \mathrm{SD}\end{array}$ & $16.7 \pm 2.4$ & $12.1 \pm 2.8$ & $11.4 \pm 3$ & 5.5 & $0.009^{*}$ \\
\hline $\begin{array}{l}\text { Obesity } \\
\text { Yes (15) } \\
\text { No }(20) \\
\end{array}$ & $1(6.7 \%)$ & $\begin{array}{l}8(53.3 \%) \\
11(55.0 \%)\end{array}$ & $\begin{array}{l}6(40.0 \%) \\
5(25.0 \%)\end{array}$ & 1.7 & 0.4 \\
\hline $\begin{array}{l}\text { Family history of } \\
\text { psoriasis } \\
\text { Yes (5) } \\
\text { No (30) } \\
\end{array}$ & $\begin{array}{c}0(0.0 \%) \\
5(16.7 \%)\end{array}$ & $\begin{array}{l}3(60.0 \%) \\
16(53.3 \%)\end{array}$ & $\begin{array}{l}2(40.0 \%) \\
9(30.0 \%) \\
\end{array}$ & 1.1 & 0.6 \\
\hline $\begin{array}{l}\text { Chronic diseases } \\
\text { Yes }(20) \\
\text { No }(15)\end{array}$ & $\begin{array}{l}2(10.0 \%) \\
3(20.0 \%)\end{array}$ & $\begin{array}{l}12(60.0 \%) \\
7(46.7 \%)\end{array}$ & $\begin{array}{l}6(30.0 \%) \\
5(33.3 \%)\end{array}$ & 0.9 & 0.6 \\
\hline $\begin{array}{l}\text { Marital status } \\
\text { Single (3) } \\
\text { Married (29 } \\
\text { Divorced (21) } \\
\text { Widow (1) }\end{array}$ & $\begin{array}{c}1(33.3 \%) \\
4(13.8 \%) \\
0(0.0 \%) \\
0(030 \%)\end{array}$ & $\begin{array}{c}1(33.3 \%) \\
16(55.2 \%) \\
1(50.0 \%) \\
1(100.0 \%)\end{array}$ & $\begin{array}{c}1(33.3 \%) \\
9(31.0 \%) \\
1(50.0 \%) \\
0(0.0 \%)\end{array}$ & 2.4 & 0.9 \\
\hline
\end{tabular}

* Statistically significant difference $(\mathrm{p}<0.05), * *$ Statistically high significant difference $(\mathrm{p}<0.001)$

Table (2): Relation between testosterone level and patients' characteristics:

\begin{tabular}{|c|c|c|c|c|c|}
\hline & Variable & $\begin{array}{c}\text { Low testosterone } \\
\text { (No: 10) }\end{array}$ & $\begin{array}{c}\text { Normal testosterone } \\
\text { (No: 25) }\end{array}$ & Test & P. value \\
\hline Age & $\begin{array}{l}\text { Mean } \pm \text { SD } \\
\text { Median }\end{array}$ & $\begin{array}{c}51.9 \pm 1.9 \\
54-5 \\
\end{array}$ & $\begin{array}{c}46.3 \pm 2.8 \\
46 \\
\end{array}$ & $\mathrm{~T}=0.6$ & 0.2 \\
\hline Disease duration & $\begin{array}{c}\text { Mean } \pm \text { SD } \\
\text { Median }\end{array}$ & $\begin{array}{c}8.7 \pm 2.5 \\
7.5 \\
\end{array}$ & $\begin{array}{c}10.2 \pm 3.8 \\
9 \\
\end{array}$ & $\begin{array}{l}\text { M.W } \\
0.5\end{array}$ & 0.6 \\
\hline Cholesterol & $\begin{array}{c}\text { Mean } \pm \text { SD } \\
\text { Median }\end{array}$ & $\begin{array}{c}210.6 \pm 53.9 \\
202 \\
\end{array}$ & $\begin{array}{c}183.4 \pm 39.6 \\
188\end{array}$ & $\mathrm{~T}=5.6$ & $0.03^{*}$ \\
\hline Family history & $\begin{array}{l}\text { Yes (5) } \\
\text { No (30) } \\
\end{array}$ & $\begin{array}{l}2(40.0 \%) \\
8(26.7 \%) \\
\end{array}$ & $\begin{array}{l}3(60.0 \%) \\
22(73.3 \%)\end{array}$ & FET & 0.5 \\
\hline Obesity & $\begin{array}{l}\text { Yes (15) } \\
\text { No (20) }\end{array}$ & $\begin{array}{l}6(40.0 \%) \\
4(20.0 \%)\end{array}$ & $\begin{array}{c}9(60.0 \%) \\
16(80.0 \%)\end{array}$ & $\begin{array}{l}\mathrm{X} 2 \\
1.6\end{array}$ & 0.2 \\
\hline Chronic diseases & $\begin{array}{l}\text { Yes (20) } \\
\text { No (15) }\end{array}$ & $\begin{array}{l}7(35.0 \%) \\
3(20.0 \%)\end{array}$ & $\begin{array}{l}13(65.0 \%) \\
12(80.0 \%)\end{array}$ & FET & 0.4 \\
\hline
\end{tabular}


papules, plaques and patches of skin varies in severity from small, localized patches to complete body coverage ${ }^{(12)}$.

Psoriasis has been recognized by the World Health Organization as a serious, disfiguring, disabling, noncommunicable disease that represents a significant public health challenge due to its psychological, social and economic burden ${ }^{(13)}$. IL-23 contributes to psoriasis by stimulating proliferation, differentiation, and maintenance of $\mathrm{T}$ helper 17 cells and innate immune cells, which produce proinflammatory cytokines such as IL-17. Importantly, discovery of the IL-23/IL-17 immunological pathway was key to our expanding knowledge about the pathogenesis of psoriasis ${ }^{(14)}$.

The aim of this study was to evaluate level of serum testosterone in psoriasis male patients and its relation to severity of the disease.

Regarding total cholesterol, the average cholesterol level among the studied group was (195.4 $\pm 43.4 \mathrm{mg} / \mathrm{dl}$ ) ranged from (131 to 325 ) which revealed increase its level in psoriatic patients and there was statistically significant increase in cholesterol level among patients with severe than moderate than mild PASI score $(\mathrm{p}$ value $=0.005)$.

This finding is in agreement with the result of Banerjee et al. ${ }^{(15)}$, El-Ghareeb et al. ${ }^{(16)}$, but it is in disagreement with the results obtained by Toker $\boldsymbol{e t}$ al. ${ }^{(17)}$ and Ahmed ${ }^{(18)}$ as they found that, total cholesterol level didn't show significant difference between the patients. It has been suggested that psoriasis, like atherosclerosis, is an autoimmune disease. Currently, considerable clinical and experimental evidence supports a considerable role for $\mathrm{T}$ cells in the pathogenesis of psoriasis and atherosclerosis. The clinical manifestation of both diseases includes inflammation that seems to be driven by certain $\mathrm{T}$-cell cytokines, characteristic for the T-helper 1 cell response ${ }^{(\mathbf{1 9 )}}$. The significant role of cytokines, such as TNF- $\alpha$, IL-6, IL-8, IFN- $\gamma$, IL-1, and IL-17 in the generation of pro-atheromatous abnormalities (dyslipidemia, insulin resistance, endothelial dysfunction, clotting system activation, and prooxidative stress) was reported ${ }^{(20)}$.

The reasons for dyslipidemia in psoriasis may be multiple. The structural and functional changes in digestive tract, immune mechanisms involving IL-6 and tumor necrosis factor, and C-reactive proteins and cellular oxidative stress may be responsible for altered lipid metabolism ${ }^{(\mathbf{2 1})}$.

From the above, it is recommended for all psoriasis patients early screening and treatment of hyperlipidemia to prevent atherosclerosis and its complications. According to the present study, the average total testosterone level was $(5.1 \pm 1.5)$ ranged from (2.91 to 7.93) and free testosterone level was (12.5 \pm 3.5$)$ ranged from (6.9 to 18.9$)$, about two thirds of the studied group $(71.4 \%)$ had normal testosterone level and $(28.6 \%)$ had low testosterone level and sexual problems and complaints so need a treatment.

These results are in agreement with Cemil $\boldsymbol{e t}$ al. ${ }^{(22)}$, Eltaweel et al. ${ }^{(23)}$ and Allam et al. ${ }^{(24)}$ findings. However, both Tehranchinia et al. ${ }^{(9)}$ and Schwarz et al. (25) reported the higher levels of serum total testosterone in healthy control subjects than psoriasis patients without reaching a statistical significance. However, in the present study, the data indicate that not only are total testosterone levels reduced but also bioactive free testosterone levels, which suggests that patients with psoriasis are likely to experience symptoms of testosterone deficiency. Our result shows that there was statistically significant higher PASI score among patients with low testosterone level than normal testosterone patients.

There were $(89.2 \% \& 10.5 \%)$ of moderate PASI Score patients had normal \& low testosterone level while $(27.5 \%$ \& $72.7 \%)$ of severe PASI score patients had normal \& low testosterone level respectively.

This result can be explained by the antiinflammatory effect of testosterone through different mechanisms. Firstly, Testosterone inhibits body fat expansion and reduces adipocytes size and metabolism.

After its aromatization in estradiol, Testosterone can activate AR and ER $\alpha$ and ER $\beta$, which contribute to adipocytes regulation decreasing the release of adipokines (leptin, IL-6, TNF-a, OPG, $\mathrm{MCP} 1 \alpha)$ and improving adiponectin and visfatin production, which possess an anti-inflammatory effect (26).

Furthermore, Testosterone improves insulin activity and reduces the CRP from the liver. Altogether, it results in a reduction of inflammation and development of chronic diseases (26).

These results is in agreement with Allam et al. ${ }^{(24)}$ who found that PASI inversely correlated with low total and free testosterone level Concerning psoriasis severity categories, significantly lower testosterone levels were detected in patients with moderate-tosevere psoriasis compared to patients with mild psoriasis . In contrast, Cemil et al. ${ }^{(22)}$ found that there was no significant correlation between PASI and serum testosterone.

\section{CONCLUSION}

It could be concluded that low serum total and free testosterone levels in male psoriasis patients are present, together with high PASI score and they correlate with disease severity.

\section{REFERENCES}


1. Afonina I, Van Nuffel E, Beyaert $R$ (2021): Immune responses and therapeutic options in psoriasis. Cellular and Molecular Life Sciences, 21: 1-19.

2. Sabry H, Hamed A, El Fallah A et al. (2020): Sirt-1 as A Predictive Marker of Metabolic Syndrome in Psoriasis Patients. Benha Journal of Applied Sciences, 5(7 part (2)): 1-3.

3. Tan L, Zhao S, Zhu W et al. (2018): The Akkermansia muciniphila is a gut microbiota signature in psoriasis. Experimental Dermatology, 27(2): 144-149.

4. Martins A, Ascenso A, Ribeiro H et al. (2020): The Brain-Skin Connection and the Pathogenesis of Psoriasis: A Review with a Focus on the Serotonergic System. Cells, 9(4): 796.

5. Chiricozzi A, Romanelli P, Volpe E et al. (2018): Scanning the immunopathogenesis of psoriasis. International Journal of Molecular Sciences, 19:179183.

6. Tonel G, Conrad C, Laggner U et al. (2010): Cutting edge: a critical functional role for IL-23 in psoriasis. $\mathbf{J}$ Immunol Baltim Md., 185(10): 5688-5691.

7. Coimbra S, Oliveira H, Reis F et al. (2010): IL 22, IL 17, IL 23, VEGF, TNF alpha and IL 8 levels in soriatic patients -before, during and after PUVA and NBUVB therapy. Br J Dermatol., 163: 1282-90.

8. Luo J, Wu S, Lacy E et al. (2010): Structural basis for the dual recognition of IL 12 and IL 23 by ustekinumab. J Mol Biol., 402: 797-812.

9. Tehranchinia Z, Niroomand M, Kazeminejad A et al. (2014): Leptin and sex hormones in psoriasis and correlation with disease severity. Iran J Dermatol., 17: 43-48.

10. Fadzil M, Prakasa E, Fitriyah H et al. (2010): Validation on 3D surface roughness algorithm for measuring roughness of psoriasis lesion. Biological and Biomedical Sciences, 7(4): 205-211.

11. Artiss J, Zak B (1997) Measurement of cholesterol concentration In: Rifai N, GR Warnick and $\mathrm{MH}$ Dominiczak, editor. Handbook of Lipoprotein Testing. Washington: AACC Press, Pp. 99-114.

12. Rendon A, Schäkel K (2019): Psoriasis pathogenesis and treatment. International Journal of Molecular Sciences, 20(6): 1475-83.

13. Iskandar I, Parisi $R$, Griffiths $C$ et al. (2021): Systematic review examining changes over time and variation in the incidence and prevalence of psoriasis by age and gender. British Journal of Dermatology, 184(2): 243-258.
14. Warren R, Blauvelt A, Poulin Y et al. (2021): Efficacy and safety of risankizumab vs. secukinumab in patients with moderate-to-severe plaque psoriasis (IMMerge): results from a phase III, randomized, openlabel, efficacy-assessor-blinded clinical trial. British Journal of Dermatology, 184(1): 50-59.

15. Banerjee S, More U, Tilak M et al. (2014): Lipid alterations in psoriasis. Indian J Basic Appl Med Res., 3(2): 350-357.

16. ElGhareeb M, Khater M, Fakhr A et al. (2019): Risk and severity of psoriasis vulgaris in relation to angiotensin II type 1 receptor gene polymorphism and metabolic syndrome. Clinical, Cosmetic and Investigational Dermatology, 12: 683-688.

17. Toker A, Kadı M, Yıldırım A et al. (2009): Serum lipid profile paraoxonase and arylesterase activities in psoriasis. Cell Biochemistry and Function, 27(3): 176180.

18. Ahmed A (2011): Serum lipid profile in Psoriasis: a controlled study. Tikrit Medical Journal, 17(1) 38-42:

19. Mallbris L, Granath F, Hamsten A et al. (2006): Psoriasis is associated with lipid abnormalities at the onset of skin disease. J Am Acad Dermatol., 54: 614 621.

20. Aldona P, Anna M, Grażyna C et al. (2010): Lipid disturbances in psoriasis: An update. Mediators of Inflammation. Mediators Inflamm, 2010:535612.

21. Bajaj D, Mahesar S, Devrajani B et al. (2009): Lipid profile in patients with psoriasis presenting at Liaquat University Hospital Hyderabad. JPMA. The Journal of the Pakistan Medical Association, 59(8): 512-518.

22. Cemil B, Cengiz F, Atas H et al. (2015): Sex hormones in male psorias is patients and their correlation with the Psoriasis Area and Severity Index. J Dermatol., 42:500503.

23. Eltaweel A, Mustafa A, El-Shimi O et al. (2018): Sex hormones, erectile dysfunction, and psoriasis; a bad friendship!. International Journal of Dermatology, 57(12): 1481-1484.

24. Allam J, Bunzek C, Schnell L et al. (2019): Low serum testosterone levels in male psoriasis patients correlate with disease severity. European Journal of Dermatology, 29(4): 375-382.

25. Schwarz W, Schell H, Hornstein O (1981): Testosterone serum levels in male psoriatics. Arch Dermatol Res., 270: 377-379.

26. Bianchi V (2019): The anti-inflammatory effects of testosterone. Journal of the Endocrine Society, 3(1): 91107. 